\title{
A COMPETENCE-BASED AND
}

\section{MULTIDIMENSIONAL}

\section{OPERATIONALIZATION AND}

\author{
MEASUREMENT OF
}

\section{EMPLOYABILITY}

\section{CLAUDIA M. VAN DER HEIJDE AND BEATRICE I. J. M. VAN DER HEIJDEN}

\begin{abstract}
Employability is a critical requirement for enabling both sustained competitive advantage at the firm level and career success at the individual level. We propose a competence-based approach to employability derived from an expansion of the resource-based view of the firm. In this contribution, we present a reliable and valid instrument for measuring employability. This measure is based on a five-dimensional conceptualization of employability, in which occupational expertise is complemented with generic competences. Two sources of raters (employees and their immediate supervisors) are involved in developing and testing the measure. Since the five dimensions of employability explain a significant amount of variance in both objective and subjective career success, the predictive validity of the tool is promising. This instrument facilitates further scientific HRM research and is of practical value in light of job and career assessments, recruitment, staffing, career mobility, and development practices. (c) 2006 Wiley Periodicals, Inc.
\end{abstract}

\section{Introduction}

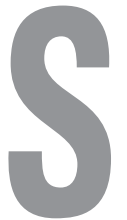

timulating occupational expertise and employability of employees appears to be advantageous for both organizational and employee outcomes (Fugate, Kinicki, \& Ashforth, 2004; Van Dam, 2004). Highly employable workers (Van Dam, 2004) are necessary for organizations in order to meet fluctuating demands for numerical and functional flexibility (Marginson, 1989; Valverde, Tregaskis, \& Brewster, 2000). In addition, em- ployability enables employees to cope with fast-changing job requirements. London and Greller (1991) refer to "loosening of organizational commitment (to markets, tradition, and employees), accommodating a more volatile and competitive environment" (adapted from Baerveldt \& Hobbs, 1988), and job content becoming more demanding, in terms of technical knowledge and skills.

Careers increasingly have become boundaryless, in the sense that during career

Correspondence to: Claudia M. Van der Heijde, Vrije Universiteit Amsterdam, Faculty of Economics and Business Administration, Department of Management and Organization, De Boelelaan 1105, Room 3A-34, 1081 HV Amsterdam, The Netherlands, Phone: +31 20 5986123, Fax: +31 6 24221277, E-mail: cheijde@feweb.vu.nl 
progression, more boundaries are crossed (e.g., occupational, departmental, and organizational) in comparison to earlier and more predictable hierarchical careers (DeFillippi \& Arthur, 1996; Gunz, Evans, \& Jalland, 2000). When careers are less predictable, a thorough diagnosis of competences, or employability, is a crucial starting point for all career policy activities. A sound measurement instrument for employability enables individual employees to keep track of their competences and career needs. Only after this assessment should workers undertake action to improve their employability-for example, by means of job-related or organizational career interventions such as mentoring, networking, and age-related HRM policy (B. I. J. M. Van der Heijden, 2005).

Increasingly, domain-specific occupational expertise is insufficient to guarantee positive work outcomes during the course of one's entire career. Unfortunately, previous research has demonstrated that many employees are not able to keep up with the faster pace of change, as investments in competence development diminish with age (Boerlijst, 1994; Thijssen, 1996). This is highly problematic, since career development is largely dependent upon initiatives and investments of the employees themselves (Hall, 1976), although it must be stimulated by the organization.

In the next section, we address the definition and domain-independent (see B. I. J. M. Van der Heijden, 2000) operationalization of the concept of employability. An overview of the theoretical framework is given, elucidating our competence-based approach as an extension of the resource-based view of the firm (Barney, 1991; Nordhaug \& Grønhaug, 1994; Wright, McMahan, \& McWilliams, 1994). This perspective enables us to align two different theories on employability: the one from Fugate et al. (2004) and the one from Van Dam (2004). Fugate et al. (2004) have career outcomes as their first focus, while Van Dam depicts organizational outcomes as her first focus of employability (more specifically, organizational flexibility).

We then discuss the development of a measurement instrument for employability, in which employability is composed of occupational expertise and four more generic competences. In the theoretical framework, the relationship to other concepts of interest concerning employability will be clarified. Subsequently, we outline our research methodologies, followed by the results of the psychometric analyses. In the discussion and conclusion, we consider the implications of our study for organizational practitioners and provide suggestions for future research.

\section{A Competence-Based Approach to Employability}

The concept of employability came into use around 1955 (Versloot, Glaudé, \& Thijssen, 1998). However, it is only since the late 1990s that employability has been empirically studied. Several historical overviews shed some light on the development of its conceptualization and definitions (Thijssen \& Van der Heijden, 2003; Van Lammeren, 1999; Versloot et al., 1998). Employability is studied from different angles and distinct levels (individual, organizational, and industrial) across a wide range of academic disciplines, such as business and management studies, human resource management, human resource development, psychology, educational science, and career theory. However, few studies have tried to integrate these different perspectives (Thijssen \& Van der Heijden, 2003).

Definitions and synonyms of the concept at the employee level are abundant (De Grip, Van Loo, \& Sanders, 2004; Forrier \& Sels, 2003; Fugate et al., 2004; Harvey, 2001; Thijssen \& Van der Heijden, 2003; B. I. J. M. Van der Heijden \& Thijssen, 2003; Van Lammeren, 1999; Versloot et al., 1998), each emphasizing a diversity of career aspects of (potential) employees but all referring to employment as an outcome. Some examples of these career aspects are physical suitability 
(Gazier, 1990), cognitive suitability, (career) development (De Haan, Vos, \& De Jong, 1994; Sterns \& Dorsett, 1994), learning, despecialization (Bolweg \& Maenhout, 1995; Hoeksema \& Paauwe, 1996; Pearson, 1988), flexibility, adaptation to (fast) changes (Bolweg, 1997; Friedrichs, 2000), and mobility (both external and internal). Employability is believed to accommodate some or all of these aspects, depending upon the angle from which the concept is studied and, consequently, it is not a unidimensional construct. Fugate et al. (2004), who recently thoroughly studied its conceptual foundation from a career angle, use the term variegated.

Apart from the large variety of employability definitions, one might be able to distinguish a link between the conceptualization of employability and certain historical work and organizational developments in Western countries (Van Lammeren, 1999; Versloot et al., 1998), in relation to the transition from an industrial to a postindustrial society (Thijssen \& Van der Heijden, 2003). Employability is a symbol used to address work-related problems related to this transition. Until the 1970s, employability was about employment participation and was accompanied by the so-called flexibility of society. The government was considered the actor responsible for achieving the target of full employment and a decrease in the collective burden (Thijssen \& Van der Heijden, 2003). During the last decades of the twentieth century, market developments compelled organizations to reorganize themselves into more flexible firms (see also Boselie \& Paauwe, 2004; Geelhoed, 1997; Van Dam, 2004). Changes are taking place at a faster rate and in increasing numbers, undermining organizational strategy and planning, and which the organizations should be potentially able to flexibly anticipate on.

These developments enforce a reorganization of the structure of work (like despecialization and deregulation) and the transition from a job-based HRM system to a competence-based person-related HRM system (Lawler, 1994; Mikkelsen, Nybø, \& Grønhaug, 2002; Rodriguez, Patel, Bright, Gregory, \& Gowing, 2002). New production

concepts, such as total quality management, lean production, business process redesign, and socio-technics (De Lange, 2001; Steijn, 2002) all decrease the division of labor and increase teamwork. These changes have implications for the ideal employee profile and the type of skills that are needed (Felstead \& Ashton, 2000). Furthermore, human capital or human resources have been gaining in importance and increasingly should be taken into account in organizational strategy making.

According to the resourcebased view of the firm (Barney, 1991; Nordhaug \& Grønhaug, 1994; Wright et al., 1994), competences are one category of possible resources that enable firms to achieve performance and (sustained) competitiveness. The resource-based view of the firm can be positioned somewhere in between so-called soft (Guest, 1987; Legge, 1995) and hard strategic HRM approaches in that it offers a framework for theorizing on and practicing balance between the interests of organizations and employees (Boxall, 1999; Looise, 1998). In such a context, employee competences are treated as valuable assets that must be nourished and are interpreted as being beneficial for both employee and organization. As such, occupational expertise and employabil-

These developments enforce a reorganization of the structure of work (like despecialization and deregulation) and the transition from a job-based HRM system to a competence-based person-related HRM system. ity provide both work continuity and careerdevelopment opportunities.

This approach is more moderate and realistic compared to using only market-driven and cost-reducing decisions for competitive strategy, and subsequently labor management (hard approach) or high-commitment models (soft approach) (Guest, 1987; Legge, 1995; Looise, 1998). A prerequisite for sustained competitive advantage (Barney, 1991; Nordhaug \& Grønhaug, 1994) consists of a unique combination of acquiring and retaining competent workers, and adequate HR policies and practices of investing in them. Boxall (1999) refers to human resource advantage in order to 


\begin{tabular}{c}
\hline Within a \\
competence-based \\
approach to \\
employability, \\
competence models \\
are used to unify \\
individual \\
capabilities with \\
organizational core \\
competences
\end{tabular}

(Rothwell \&

Lindholm, 1999).

Besides vertical and

horizontal alignment,

Mulder (2001)

stresses the

following functions

of the concept:

strategic las a route

planner),

communicative

lyielding

transparency),

dynamic,

developmental,

employability, and

performance

improvement. stress the positive outcomes of this combination.

Within a competence-based approach to employability, competence models are used to unify individual capabilities with organizational core competences (Rothwell \& Lindholm, 1999). Besides vertical and horizontal alignment, Mulder (2001) stresses the following functions of the concept: strategic (as a route planner), communicative (yielding transparency), dynamic, developmental, employability, and performance improvement. Athey and Orth (1999, p. 216), define competency as "a set of observable performance dimensions, including individual knowledge, skills, attitudes, and behaviors, as well as collective team, process, and organizational capabilities, that are linked to high performance, and provide the organization with sustainable competitive advantage." In the conceptualization that is central in this article, competence is defined at an individual level.

While in practice, the terms competence and skills are often used simultaneously, it might prove illuminating to elaborate on the distinction between the two. Skill concerns the execution of a single task, while competence deals more with the execution of a whole series of different tasks in a certain (occupational) domain, all of them performed well and in an integrated manner (Mulder, 2001; Onstenk, 1997). This integrating and synergetic process into competence and competent action is then enacted with the aid of different personal qualities such as motivation, attitudes, behavior, and personality.

In the remainder of this section, our line of thought will be elaborated upon by referring to some competence approaches, definitions, the functional use of the concept, and its added value, all directed toward the development of an employability theory. First of all, insights from a rationalist versus an interpretative approach to competence are dealt with and integrated. Sandberg (2000) describes the rationalist approach toward human competence as an attribute-based phenomenon. In this approach, workers with better knowledge and skills will automatically outperform others. In the past, competence was more about potential, qualification, or IQ (McClelland, 1973), and was also referred to as competency (Mulder, 2001).

Increasingly, the emphasis lies on the application of potential (knowledge and skills) (see also Athey \& Orth, 1999; Mulder, 2001). Accordingly, in his interpretative approach to human competence at work, Sandberg (2000) points to the importance of the knowledge and skills people use when working. In this approach, conceptions, rather than attributes, determine the level of competence of individual workers. The experience gained by employees determines the framework or mind-set from which the work is undertaken, and subsequently, the goals set (motivation) and the means, such as knowledge and skills, that are deployed to do the work.

Cognition and emotion both contribute to the development of competence. According to Sternberg (1996), success in work is not restricted to IQ or technical skill but is a result of the balance between cognition and emotion. Sternberg (1999, p. 438) defines successful intelligence as "the ability to balance the needs to adapt to, shape and select environments in order to attain success (however within one's sociocultural context)." Limiting this definition to a working environment, it can be regarded as a synonym for the concept of employability.

One example of how conceptions may contribute to the attainment of competence can be found in work by Dweck and Leggett (1988), in their social-cognitive approach to motivation and personality. They describe the role played by the mind-set of 
orienting people toward certain goals (learning orientation vs. performance orientation) leading to adaptive or maladaptive behavioral patterns, and thereby addressing the mechanism through which personal attributes interact.

Another powerful concept in light of our employability model is self-efficacy. Self-efficacy refers to "beliefs in one's capabilities to mobilize the motivation, cognitive resources, and courses of action needed to meet given situational demands" (Wood \& Bandura, 1989, p. 408). However, it is not only the beliefs about one's capabilities, but also one's beliefs about working life and work content (e.g., beliefs on the usefulness of the work, beliefs in certain work methods, moral beliefs) that might influence a person's motivations, actions, and performance.

The dynamic component of the concept of competence points to its process character (Orlikowski, 2002; Scarbrough, 1998). Th. Van der Heijden, Volz, Reidinga, and Schutte (2001) define competence management at an organizational level as "the continuously integrated fine tuning of competences and talents" (p. 27). In the current study, employability is defined as "the continuous fulfilling, acquiring or creating of work through the optimal use of competences" (Van der Heijde \& Van der Heijden, 2005, p. 143). This definition is compatible with definitions like "the chance for employment on the internal or external labor market" (Forrier \& Sels, 2003) and "a form of work-specific active adaptability that enables workers to identify and realize career opportunities" (Fugate et al., 2004).

Building on its dynamic character, another important dimension of the concept (Onstenk, 1997) is that learning and development for the employee is a means for adapting to change. Correspondingly, core competence at an organizational level is perceived as collective learning (Prahalad \& Hamel, 1990). The concepts of continuous professional development (CPD) and lifelong learning (LLL) are often mentioned with regard to the employability theme. As such, competence development is measured by determining the applicability of knowledge and skills or possible transfer. The degree of transfer is characterized by the extent to which contexts differ and in which the learned material can be applied (Perkins \& Salomon, 1992). However, transfer of competences in the sense of so-called learning, which is about the application of knowledge and skills in divergent working situations, is often lacking (Cheng \& Ho, 2001), although it is fundamental for employability enhancement.

To summarize some key elements, (1) employability is advantageous for both career outcomes and firm outcomes; (2) at the employee level, employability is advantageous for both present performance on the job as well as career outcomes (long-term performance, implying the process of adaptation and learning); (3) besides adaptive behavior, employability may contain personal elements such as personality, attitudes, motivation, and ability; and (4) employability represents the combination of specific and more generic competence.

\section{Dimensions of Employability}

This section addresses the competence-based conceptualization of employability, in which the dimension of occupational expertise is complemented with four more general competences: (1) anticipation and optimization, (2) personal flexibility, (3) corporate sense, and (4) balance. There is clear evidence, from both strategic HRM (Capelli \& Crocker-Hefter, 1996; Wright \& Snell, 1998) and from career theory (Miles \& Snow, 1996), of the importance of a broader competence package. More specifically, there also is evidence of an increase in the importance of adaptive and social competences (Rodriguez et al., 2002) alongside domain-related knowledge and skills in jobs, following the evolution in organizational form. The proposed employability dimensions relate to job-related matters as well as aspects of a broader career development. Taking into account the inter- 
ests of both employees and employers, we have adopted a dual orientation, both toward the development of human potential and toward the development of the work process (see Van der Krogt, 1998).

In times of recession, workers most likely to be made redundant are the ones whose occupational expertise is lacking, obsolete, or outdated.

The first dimension of employability that is taken to be a prerequisite for positive career outcomes of workers is referred to as occupational expertise. A number of authors, including Boudreau, Boswell, and Judge (2001) and Onstenk and Kessels (1999), claim that occupational expertise constitutes a substantial element of employability. Occupational expertise also is seen as a significant human capital factor for the vitality of organizations. Furthermore, due to the intensification of knowledge, its importance is only growing (Enders, 2002; Schein, 1996; B. I. J. M. Van der Heijden, 2005).

In times of recession, workers most likely to be made redundant are the ones whose occupational expertise is lacking, obsolete, or outdated. According to DeFillippi and Arthur (1996), people with occupational expertise derive greater benefit from interfirm career opportunities. For the measurement of occupational expertise, our first dimension of employability (see B. I. J. M. Van der Heijden, 2000), we used an instrument originally developed to measure professional knowledge and skills, including meta-cognitive ones. This measure also accounts for social recognition by important key figures. Aside from a high degree of knowledge and skills related to a particular professional domain, experts need to be perceived and labeled as high performers and excellent professionals if they are to have a basis for employability enhancement.

The second and third dimensions of employability concern adapting to changes and developments at a job-content level and at other levels, such as the career as a whole, that are relevant in the light of performance outcomes. An important component of employability described by Kluytmans and Ott (1999) is the "willingness to adapt to changes in terms of employment, job contents, conditions, or locations." Future changes that might influence the work context of employees include, for example, mass unemployment and reorganization. In our employability framework, two different types of adaptation are distinguished, the first one being a self-initiating proactive variant that is referred to as anticipation and optimization, and one more passive, reactive variant entitled personal flexibility. Both adaptation types coexist and function to enhance the employability of the professional worker.

Anticipation and optimization does not concern adaptation in its basic form, but rather entails preparing for future work changes in a personal and creative manner in order to strive for the best possible job and career outcomes (Bhaerman \& Spill, 1988; North, Mallabar, \& Desrochers, 1988). Increasingly, employees have to enact their jobs and their professional life themselves (Weick, 1996), owing to the complexity of work and difficulty of employers to predict future work content. In present-day, knowledge-intensive markets, employees certainly have an opportunity to fulfill labor requirements by creating the future themselves instead of merely performing fixed tasks. In the employability career approach adopted by Fugate et al. (2004), "person centered active adaptation and proactivity conceptually underpin the construct of employability." Similarly, studies on proactive personality summarized by Crant (2000) suggest this to be "an important element of employee, team, and firm effectiveness."

Career management will be optimized when fine-tuning is achieved between personal preferences and market developments. Labor market knowledge (Gaspersz \& Ott, 1996) is an essential element in planning a career. Ball (1997) similarly proposes an optimization dimension of career competence for labor market position improvement, although it is different in content from the proposed dimension in our instrument. 
Personal flexibility does not relate to flexibility at the content level of a job. Besides creative adaptability, employees must passively adapt to changes occurring in their work and labor market environment that they did not choose. As well as referring to the capacity for smooth transitions between jobs and between organizations, the concept encompasses adapting easily to all kinds of changes in the internal and external labor market. Numerous changes in organizations and their environments, such as mergers and reorganizations, call for flexible employees at multiple levels. In addition, they make great demands upon people's resilience. Reorganizations require employees who cope easily with, and recover readily from, disappointments. As the temporal and spatial structures of organizations change, a greater variation in working time and place occurs. An example can be seen in phenomena such as flexible warehousing and telework. Another source of variation is the employee's pool of colleagues or the peer group, which is more often subject to changes.

The dimension of personal flexibility has been deemed an important ingredient of employability by other researchers (see, e.g., Boudreau et al., 2001; Fugate et al., 2004) and has been labeled adaptability. We consider personal flexibility to be the opposite of so-called rigid behavior, and in that sense a prerequisite for and ingredient of adaptation. Employees with high scores for personal flexibility will derive greater benefit and further their career development from different experiences because they welcome changes. Flexible employees expose themselves more easily to changes and have a better understanding of how to take advantage of changes.

It is not difficult to appreciate that organizations have much to gain from flexible employees. Regarding numerical flexibility, hiring temporary workers provides organizations with the security of not spending too much on personnel costs in times of decline. Another positive side effect lies in the fact that the core of people working in the organization benefit as they experience less competition for promotions (Barnett \&
Miner, 1992), and for lifetime employment (Baruch, 2001) (see Barnett \& Miner, 1992, for an elaborate overview and more details on this matter). This side effect provides continuity in work and career development for a certain group of employees (although at the expense of the others-that is to say, the temporary workers) and to the organization as a whole.

The fourth dimension of employability is corporate sense. The erosion of the traditional dichotomy between managers and support staff means that employees have to participate more as members of an integrated team, identify with corporate goals, and accept collective responsibility for the decision-making process (Chapman \& Martin, 1995). Besides that, corporate sense extends the organizational citizenship behavior concept (Podsakoff, MacKenzie, Paine, \& Bachrach, 2000) to participation and performance in different workgroups, such as the department, the organization, working teams, the occupational community, and other networks. The number of groups to which employees may belong has increased tremendously in recent decades (Frese, 2000; Seibert, Kraimer, \& Liden, 2001). Besides departmental and organizational collaboration, employees may participate in project networks, occupational networks, industry networks, and virtual networks, to mention but a few. Corporate sense builds on social capital (networks) (Nahapiet \& Ghoshal, 1998; see also the special issue of the Academy of Management Executive guest-edited by Rosalie L. Tung [Vol. 17(4)]), social skills, and emotional intelligence (Mayer \& Salovey, 1997). It is about sharing responsibilities, knowledge, experiences, feelings, credits, failures, goals, and the like.

The last dimension of employability that is distinguished in our employability framework is termed balance. Balance is defined as compromising between opposing employers' 
interests as well as one's own opposing work, career, and private interests (employee) and between employers' and employees' interests. Paauwe

While we are aware

of rater bias among

supervisors

(Thornton \& Byham,

1982), we

nevertheless wish to

emphasize the use

of this group of

raters with regard to

the key role played

by their perception

in the career

progress of the

employee. Moreover,

self-ratings have

been demonstrated

to be more reliable

when employees are

aware that ratings

are also being given

by their supervisors,

because the

leniency effect is

suppressed.
(1997) claims that employability is out of the question without an honest exchange relationship between employer and employee, a relationship where both parties balance their investments and profits (see also Bolweg \& Maenhout, 1995; Van Dam \& Thierry, 2000, on the exchange theory).

Working life is characterized by strongly competing demands that are not easily balanced. Increasingly, organizations have to deal with paradox (Handy, 1994). Organizations often refer to employability as the deployment of their personnel, a terminology that implies pawns without initiative that can be moved around like chess pieces, while at the same time, employability refers to highly self-reliant and self-managing employees. Moreover, organizations ask for highly committed and at the same time highly flexible employees. Bolweg and Maenhout (1995) refer to the so-called management paradox to indicate this development. Another paradox with which employees are confronted is the need to both specialize and despecialize. According to Weick (1996), being able to alternate between these two is highly beneficial in present-day boundaryless careers. Employees also have (increasing!) interests that are difficult to unite, at the work process level, (career) developmental level, and private level (Bolweg \& Maenhout, 1995; Van Beckhoven, 1997).

\section{Research Methodology}

The measurement of employability presented in this article is based upon the idea that some characteristics of expert performance and of employability are valid regardless of the domain of expertise of a particular professional (see also B. I. J. M. Van der Heijden, 2000, for a more elaborate discussion on the aim and value of a domain-independent tool). The proposed five dimensions of employability are measured by means of five measurement scales ranging in length from seven to fifteen items scored on a six-point rating scale. Examples of scale anchors are as follows: not at all, to a considerable degree, never, and very often. For a full outline of all scale items, see Appendix A.

\section{Sample and Procedure}

The sample selected to test the psychometric qualities of the measurement instrument consists of two groups of respondents: the employees themselves and their immediate supervisors. One effective and valid manner for measuring a concept is to use multiple measurements and preferably to use both objective as well as subjective measurements, since these provide different perspectives (Borman, 1974; Klimoski \& London, 1974). However, qualitative dimensions of work performance are known to be difficult to obtain from objective measurements (Hennessey \& Bernardin, 2003). For this reason, we opted for supervisor ratings along with self-ratings to best capture the behaviors beneficial to improving work and career outcomes.

While we are aware of rater bias among supervisors (Thornton \& Byham, 1982), we nevertheless wish to emphasize the use of this group of raters with regard to the key role played by their perception in the career progress of the employee. Moreover, selfratings have been demonstrated to be more reliable when employees are aware that ratings are also being given by their supervisors (Mabe \& West, 1982), because the leniency effect is suppressed (Arnold \& MacKenzie Daveys, 1992; Campbell \& Lee, 1988; Harris \& Schaubroeck, 1988; Hoffman, Nathan, \& Holden, 1991; Holzbach, 1978). We test for rater bias in supervisor and self-ratings in the validity analyses and report these in our results. 
Data were gathered during the autumn and winter of 2002, in a large Dutch firm that produces building materials. Two nominally identical versions of the questionnaire were used: one employee version (the self-rating version) and one supervisor version. The supervisors filled out a questionnaire that contained amended items worded to express the extent of employability of their respective employees. Most employees of the firm were included in the study and were asked directly by their supervisors to participate. Each supervisor had to complete employability questions on their subordinates. Questionnaires were limited to a maximum of three employees per supervisor for practical (time restrictions) and reliability reasons (B. I. J. M. Van der Heijden, 2000).

The selection of employees was restricted to those with at least middle educational levels of functioning, in order to provide data that could be generalized for future use in organizations. It was necessary to allow for the possibility that current workers, particularly older ones, might not be comparable with employees hired by companies in, say, 20 years (see also B. I. J. M. Van der Heijden, 2005).

Our final research sample consisted of 314 employees and 334 immediate supervisors (i.e., 290 pairs). The employees worked in numerous types of jobs at middle and higher educational levels. For the employees, 83.3\% were male, $84.8 \%$ of them were married or cohabiting, $11.2 \%$ were single, and $3.9 \%$ were divorced at the time of the study. Regarding their education level, $0.8 \%$ had only a primary education, $40.9 \%$ had a high school degree (or recognized equivalent), 30.8\% had basic vocational education (or recognized equivalent), $15.3 \%$ had a BA, $2.2 \%$ had an MA, and none of the employees had a doctorate.

\section{Development of the Questionnaire}

Different methods exist for constructing measurement instruments representing abstract concepts. Each has specific advantages and disadvantages. Oosterveld and Vorst (1996, p. 2) refer to them as "risks for a valid measure- ment." In order to benefit from various advantages and to decrease the number of disadvantages, we have opted for a combination of methods. The effectiveness, usefulness, or the so-called instrumental utility of an operationalization comprises validity, accuracy (reliability), and efficiency. It reflects how useful or how valuable the operational definition is in its aim to represent the concept as intended in a certain research context (De Groot, 1961).

A multidimensional construct can be measured by using different subscales that measure the different component dimensions. The process of item formulation for each scale should be related to underlying theoretical assumptions, including the statistical method to test these assumptions (Kidder \& Judd, 1986). In our study, both the validity and reliability of the instrument were optimized by means of an analysis of relevant theoretical literature (Step 1), and by using statistical validation techniques. The employability instrument is a compound instrument consisting of five dimensions, which can also be considered as a set of five instruments (De Groot, 1961). Steps two (determinaton of the employability dimensions) and three (provisional item
The selection of employees was

restricted to those with at least middle educational levels of functioning, in order to provide data that could be generalized for future use in organizations. formulation for the different dimensions) led to an item pool for each dimension of the concept of employability.

The first dimension was measured using a previously developed instrument for professional expertise (B. I. J. M. Van der Heijden, 2000). The scales in the original instrument each contained 12 to 19 items but were reduced to a maximum of 10 items in order to enhance the user-friendliness, efficiency, and symmetry of the scales. Items were reduced by means of a renewed content analysis of the existing scales by an expert group of scientists, followed by a reliability analysis and an exploratory factor analysis. Some scales of the professional expertise instrument gained increased validity, as some items that displayed overlap with the supplementary employability 
scales were removed (Step 4). Moreover, a thorough linguistic evaluation of the different items was also taken into account (Step 5 ), followed by a formulation of the introduction and instructions for respondents (Step 6). The data col-

In order to support

the idea of

multidimensionality

of a concept, items

within subscales

should display

higher

intercorrelations

compared with

items from different

subscales. lection, using e-questionnaires, took place during the autumn and winter of 2002 (Step 7).

Different methods of test construction (Oosterveld \& Vorst, 1996) were used to further enhance the psychometric qualities of the instrument. These methods examined the different items, both their content and their psychometric qualities. Both convergent and divergent item validity and criterion validity were examined. Subsequently, the homogeneity of these scales was tested and optimized using Cronbach's alpha and factor analytic techniques. Part of the data analysis (Step 8) was performed at the item level. Both convergent and divergent item validity were investigated by studying the correlation structure of all items in the five measurement scales. In order to support the idea of multidimensionality of a concept, items within subscales should display higher intercorrelations compared with items from different subscales. However, the component subscales of one (multidimensional) construct should also be positively correlated (Kidder \& Judd, 1986). Items that did not discriminate sufficiently were eliminated.

Subsequently, correlations were studied between the scale scores of the employees and the scale scores of the supervisors. The latter research step assesses criterion validity. Multiple regression analysis was used for this purpose. All research steps together, combined with rechecking the content validity of the items, led to the elimination of a considerable number of items (Step 9). The goal of the procedure as a whole was to obtain a valid, though parsimonious representation of the whole concept of employability.

\section{Measures with Regard to Predictive Validity}

Objective career success was measured using four single items. Objective hierarchical success was measured as the number of promotions. Number of promotions was defined as "any increase in hierarchical level and/or any significant increase in job responsibilities or job scope employees have experienced since joining your current organization" (organization-specific objective hierarchical success [first item]) and in your entire career (overall objective hierarchical success [second item]). Objective financial success was measured, as current gross income (per month) (third item). The fourth item was number of periods of unemployment of longer than one month in the entire career.

Subjective career success was measured using the measurement scales from Gattiker and Larwood (1986). These scales consist of an organizational (job satisfaction, interpersonal success, hierarchical success, financial success) and a nonorganizational (life satisfaction) component. A sample item is "I am drawing a high income compared to my peers." The items require responses on a fivepoint format: (1) does not apply at all to (5) applies a great deal.

\section{Results}

Tables Ia and Ib show the means, standard deviations, reliability coefficients, and correlations between all study variables. All five scales appear to be homogeneous for both groups of raters $\left(N_{\text {employees }}=314, N_{\text {supervisors }}=\right.$ 334) with Cronbach's alphas for the five measurement scales varying from .78 to .90 for the self-ratings and from .83 to .95 for the supervisor ratings. It is interesting that the alpha coefficients for the supervisor ratings all are higher compared to the corresponding ones for their employees. It could well be that the ratings by employees reflect a reliable and valid but somewhat more differentiated self-image. The outcomes might also be attributed to a halo effect. Empirical studies have shown that a halo effect is less prominent in self-ratings compared with rat- 
ings by others (Hoffman et al., 1991; Holzbach, 1978; Thornton, 1980).

Paired samples $t$-tests confirm that, for each scale, the self-ratings are systematically higher than the corresponding supervisor ratings. In other words, the previously mentioned leniency effect (Arnold \& MacKenzie Daveys, 1992; Campbell \& Lee, 1988; Harris \& Schaubroeck, 1988; Hoffman, Nathan, \& Holden, 1991; Holzbach, 1978), the tendency of employees to provide a somewhat rosier image of themselves, was found in our data. The rating differences might also be explained by the fact that supervisors, in their roles as (stringent) judges of their employees' performance and behavior, tend to emphasize the negative side relatively more than the positive side of employee functioning. In other words, the so-called hardness effect might also be a contributing factor (Oosterveld \& Vorst, 1996). All intermethod correlations are significant and positive. The con- vergence of two indicators of one and the same employability scale supports the validity of both (Cronbach, 1990). The correlations range from $r=.21$ to $r=.39$.

\section{Multitrait-Multimethod Analysis}

A multitrait-multimethod (MTMM) analysis (Campbell \& Fiske, 1959) was performed in order to check convergence and divergence of our multidimensional instrument. A multitrait-multimethod analysis provides insight into the amount of variance that is caused by the kind of method that has been used (method variance) and the degree of variance that is explained by the trait or concept. In a multitrait-multimethod analysis, at least two traits are measured by at least two maximally different methods. Convergent validity demonstrates that the two different methods really measure the same underlying traits or concepts. Discriminant

\section{Means and Standard Deviations for Variables Under Study}

$\left(\boldsymbol{N}_{\text {employees }}=314, \boldsymbol{N}_{\text {supervisors }}=334\right)$

1 Age of employee

2 Years of working experience of employee

3 Age of supervisor

4 Length of time supervising this employee

5 Occupational expertise (self-ratings)

6 Anticipation and optimization (self-ratings)

7 Personal flexibility (self-ratings)

8 Corporate sense (self-ratings)

9 Balance (self-ratings)

10 Occupational expertise (supervisor ratings)

11 Anticipation and optimization (supervisor ratings)

12 Personal flexibility (supervisor ratings)

13 Corporate sense (supervisor ratings)

14 Balance (supervisor ratings)

15 Number of promotions in the company

16 Number of promotions in the career

17 Monthly gross income (EURO)

18 Periods of unemployment $>1$ month in career

19 Job satisfaction

20 Interpersonal career success

21 Hierarchical career success

22 Financial career success

23 Life satisfaction

\begin{tabular}{rr}
\multicolumn{1}{l}{ M } & \multicolumn{1}{c}{ SD } \\
40.94 & 9.20 \\
20.54 & 10.58 \\
42.95 & 7.79 \\
2.73 & 1.30 \\
4.78 & .43 \\
3.72 & .66 \\
4.44 & .49 \\
4.13 & .72 \\
4.30 & .51 \\
4.36 & .67 \\
3.49 & .71 \\
3.92 & .67 \\
3.90 & .72 \\
4.17 & .54 \\
1.34 & 1.63 \\
3.46 & 2.40 \\
266.30 & 1328.63 \\
.27 & .92 \\
3.51 & .47 \\
4.00 & .39 \\
3.35 & .57 \\
2.92 & .64 \\
4.36 & .43
\end{tabular}

a Years of supervision was measured using the following classifications: $1=<1$ year; $2=1-2$ years; $3=3-4$ years; $4=5-6$ years; $5=\geq 7$ years. 


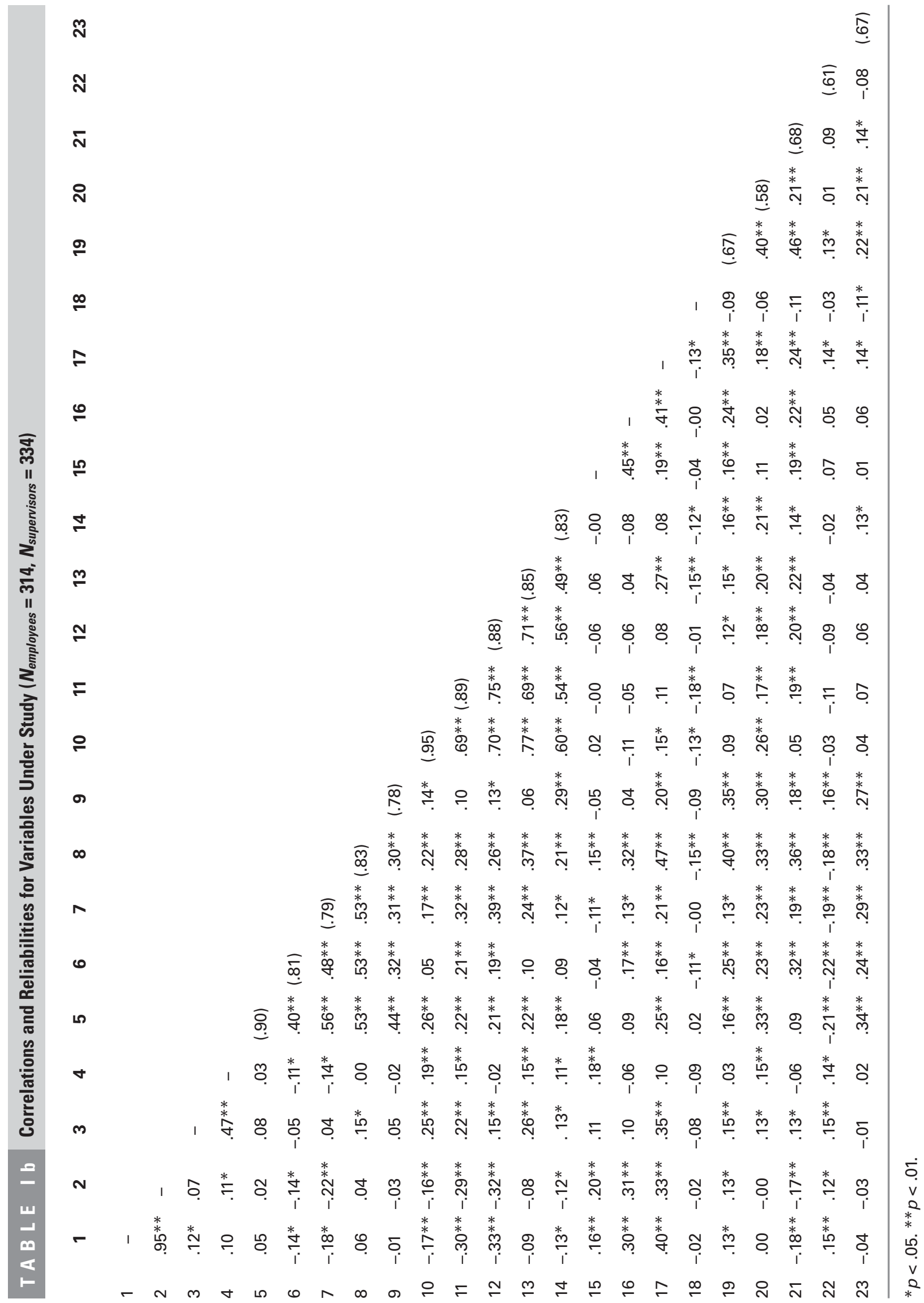


validity demonstrates that the underlying traits or concepts are really different traits or concepts. Table II shows the correlations between all traits (or dimensions) we have measured with the two different methodsthat is, the self-ratings and the supervisor scales.

Convergent validity is determined by the mono-trait, hetero-method correlations, the underlined values in Table II. According to Campbell and Fiske (1959), convergent validity can be demonstrated if these values are "significantly different from zero and sufficiently large to encourage further examination of validity." In their excellent article, they label .46 and .40 as "impressive validity values." Our validity values are less impressive but certainly indicative of a valid operationalization of the concept of employability.

Facteau and Craig (2001, p. 215) state, "Perhaps one of the most consistent findings in the empirical literature on performance appraisal systems is that the ratings obtained from different sources generally do not converge." They tested for the structure of a multifaceted construct evaluated by four different rater groups (supervisors, peers, subordinates, and self-ratings) and demonstrated the equivalent structure of the construct among the rater groups despite nonconvergence, and advocate the comparability of the different rater group scores. Likewise, Oosterveld and Vorst (1996) mention that a larger part of the variance can often be accounted for by the methods used to measure a trait rather than the trait itself (see also B. I. J. M. Van der Heijden \& Verhelst, 2002).

The proposed multidimensional character of our instrument requires outcomes demonstrating the significance and validity of distinguishing between the different scales, the discriminant validity. Discriminant validity is indicated by means of three outcomes (Campbell \& Fiske, 1959). Firstly, the heterotrait-heteromethod correlations (gray, not underlined, in Table II) need to be lower than the monotrait-heteromethod correlations (gray, underlined). Correlations between different traits measured with different methods should be lower than correlations between the same traits measured with different methods. Our data give us good reason to assume that different meanings, or concepts, are indeed reflected by the five scales. Only in the case of the anticipation and optimization scale have exceptions been found, in that there are three heterotrait-heteromethod values exceeding the monotrait-heteromethod value (.21) of

\section{T A B L E I Correlation Matrix Following the Multitrait-Multimethod Approach; Self-Ratings $(N=314)$ and Supervisor Ratings $(\boldsymbol{N}=\mathbf{3 3 4}$ ) Including Cronbach's Alphas and Interscale Correlations}

\begin{tabular}{|c|c|c|c|c|c|c|c|c|c|c|}
\hline & \multicolumn{5}{|c|}{ Self } & \multicolumn{5}{|c|}{ Supervisor } \\
\hline & 1 & 2 & 3 & 4 & 5 & 1 & 2 & 3 & 4 & 5 \\
\hline \multicolumn{11}{|l|}{ Self } \\
\hline 1. Occupational expertise & $(.90)$ & & & & & & & & & \\
\hline 2. Anticipation and optimization & .40 & $(.81)$ & & & & & & & & \\
\hline 3. Personal flexibility & .58 & .48 & (.79) & & & & & & & \\
\hline 4. Corporate sense & .53 & .53 & .53 & $(.83)$ & & & & & & \\
\hline 5. Balance & .44 & .32 & .31 & .30 & (.78) & & & & & \\
\hline \multicolumn{11}{|l|}{ Supervisor } \\
\hline 1. Occupational expertise & .26 & .05 & .17 & .22 & .14 & (.95) & & & & \\
\hline 2. Anticipation and optimization & .22 & .21 & .32 & .28 & .10 & .69 & (.89) & & & \\
\hline 3. Personal flexibility & .21 & .19 & .39 & .26 & .13 & .70 & .75 & $(.88)$ & & \\
\hline 4. Corporate sense & .22 & .10 & .24 & .37 & .06 & .77 & .69 & .71 & $(.85)$ & \\
\hline 5. Balance & .18 & .09 & .12 & .21 & .29 & .60 & .54 & .56 & .49 & $(.83)$ \\
\hline
\end{tabular}


the scale. This relatively low correlation is perhaps an indication that supervisor and employee disagree more with regard to this dimension than the other dimensions.

Second, the heterotrait-monomethod values (white areas in Table II) need to be lower than the monotrait-heteromethod values (grey, underlined). Correlations between different traits measured with the same method should be lower than correlations between the same traits measured with different methods. This requirement is not met (see Table II), owing to the greater method variance (Facteau \& Craig, 2001). Moreover, according to Campbell and Fiske (1959), the heterotrait-monomethod values should not converge with the reliability coefficients (Cronbach's alpha). Fortunately, our results are in line with this requirement and lead us to conclude that the outcomes are satisfactory.

The third test of discriminant validity requires that the patterns of correlations for each set of raters should be similar. This means that the interscale correlations should be lower than the within-scale homogeneities, both for the self-ratings and the supervisor ratings. Table II indicates that this requirement is fully met. Overall, while examining the multitrait-multimethod matrix it is obvious that the criteria of convergent and discriminant validity are met to a reasonable extent.

\section{Structural Equation Modeling}

Finally, we performed analyses based upon structural equation modeling (SEM) techniques, using the AMOS 4.0 program (Arbuckle \& Wothke, 1999), in order to investigate whether the conceptualization of employability is exhaustive-that is, covers all possible aspects or dimensions. Several alternative models were tested to find a model with the best fit. This modeling was performed at the item level. Alternative models were compared to a second-order confirmatory factor analysis (CFA), which in our case is the hypothesized structure of employability. In this model, employability is presented as a latent variable, and so are its subdimensions: (1) occupational expertise, (2) anticipation and optimization, (3) personal flexibility, (4) corporate sense, and (5) balance.

The alternative models (Table III) comprise, respectively, a null model with all the items and their error terms (no latent constructs), a one-factor model in which employability is measured by all the items (no distinction between employability dimen-

T A B L E I I I Confirmatory Factor Analysis of the Employability Measurement Instrument (SEM)

Competing Model (47 items)

Employee

Null model

One-factor model

Uncorrelated factors model

Correlated factors model

Hierarchical model (second order)

Supervisor

Null model

One-factor model

Uncorrelated factors model

Correlated factors model

Hierarchical model (second order)

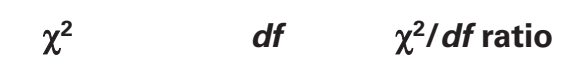

5.76

2.93

2.40

1.94

1.95

1029

$2004.8 * * *$

$\begin{array}{rr}11440.8 * * * & 1081 \\ 3999.6 * * * & 1034 \\ 3834.6 * * * & 1034 \\ 2799.0 * * * & 1024 \\ 2821.2 * * * & 1029\end{array}$

$\begin{array}{cc}10.58 & .162 \\ 3.87 & .089 \\ 3.71 & .086 \\ 2.73 & .069 \\ 2.74 & .069\end{array}$

Target

RMSEA Coefficient

.114
.073
.062
.055
.051

.99

.99

*** $p<.001$. 
sions), a first-order model that measures the five employability dimensions separately (uncorrelated), and a first-order model in which the five employability dimensions are correlated (correlated factors model).

In accordance with previously established multivariate normal distributions, we relied on maximum likelihood estimation of covariance matrices. The goodness-of-fit of the model was evaluated using absolute indices, which are more useful when using the AMOS full information maximum likelihood (FIML) estimation for missing data in the AMOS program. The absolute goodness-of-fit indices calculated were the chi-square $\left(\chi^{2}\right)$ measure, the normed chi-square measure $\left(\chi^{2} / d f\right)$ (Jöreskog, 1969), and the Root Mean Square Error of Approximation (RMSEA). According to Schumacker and Lomax (1996), a $\chi^{2} / d f$ ratio between 1 and 5 is an indication that the hypothesized model fits the data, and RMSEA values below or equal to .08 are indicative of an acceptable fit (Cudeck \& Browne, 1993). Subsequently, the target coefficient (Marsh, 1987) was calculated, measuring that part of the covariances among the first-order factors that is explained by the second-order factor (the ratio of the chi-square of the correlated first-order model to the chisquare of the second-order model, with a maximum of 1 , indicates that all covariances are explained by the second-order factor).

The SEM analyses are performed twice, once for the self-ratings and once for the supervisor ratings. In Table III, the results of the SEM analyses for the self-ratings and for the supervisor ratings are presented. For both self-ratings and for the supervisor ratings, an acceptable fit was obtained for the secondorder model (for the self-ratings: $\chi^{2}(1029)=$ $2004.8, p<0.001, \chi^{2} / d f=1.95$, RMSEA $=.051$; for the supervisor ratings: $\chi^{2}(1029)=2821.2$, $p<0.001, \chi^{2} / d f=2.74$, RMSEA $\left.=.069\right)$ and the correlated first-order model (for the selfratings: $\chi^{2}(1024)=1981.1, p<0.001, \chi^{2} / d f=$ 1.94 , RMSEA $=.055$; for the supervisor ratings: $\chi^{2}(1024)=2799.0, p<0.001, \chi^{2} / d f=$ 2.73, RMSEA $=.069$ ).

Regarding the second-order model, indices of the self-ratings were especially promising, as compared to the supervisor ratings, although the decrease of the indices across the alternative models was the same for the supervisor ratings as for the self-ratings. This is an indication of an equivalent structure of the construct among the rater groups (see also Facteau \& Craig, 2001). The target coefficient for both self-ratings and supervisor ratings, with regard to the first-order correlated model (baseline) and the hypothesized second-order model, is .99. From this finding, we conclude that $99 \%$ of the covariation among the five first-order factors is explained by the second-order factor of employability.

In Table IV, the standardized first-order factor loadings of the second-order model are presented (the supervisor outcomes are given in parentheses). They are all statistically significant, with $t$-values varying between 4.84 and $10.12(p<.001)$ for the self-ratings and t-values varying between 6.45 and $16.45(p<.001)$ for the supervisor ratings. Moreover, the standardized second-order factor loadings suggest strong relations of the indicators with the latent variable employability (self-ratings: .81 for occupational expertise, . 71 for anticipation and optimization, .87 for personal flexibility, .79 for corporate sense, and .53 for balance). For the supervisors these are .88 for occupational expertise, .87 for anticipation and optimization, .91 for personal flexibility, .93 for corporate sense, and .63 for balance. The combined results of our study argue in favor of accepting our hypothesized second-order employability model.

\section{Predictive Validity}

To demonstrate the predictive validity of the employability measurement instrument for career success, hierarchical regression analyses were performed, using both objective and subjective career success measures (Gattiker $\&$ Larwood, 1986). This enabled us to better 


\section{T A B L E I V Hierarchical CFA: Standardized Factor Loadings per Item and Dimension (SEM)}

(Supervisor in Parentheses)

Occupational expertise1

Occupational expertise2

Occupational expertise3

Occupational expertise4

Occupational expertise 5

Occupational expertise6

Occupational expertise7

Occupational expertise8

Occupational expertise9

Occupational expertise10

Occupational expertise11

Occupational expertise12

Occupational expertise13

Occupational expertise14

Occupational expertise15

Anticipation and optimization1

Anticipation and optimization2

Anticipation and optimization3

Anticipation and optimization4

Anticipation and optimization5

Anticipation and optimization6

Anticipation and optimization7

Anticipation and optimization8

Personal flexibility1

Personal flexibility2

Personal flexibility3

Personal flexibility4

Personal flexibility5

Personal flexibility6

Personal flexibility 7

Personal flexibility8

Corporate sense1

Corporate sense2

Corporate sense3

Corporate sense 4

Corporate sense5

Corporate sense6

Corporate sense7

Balance1

Balance2

Balance3

Balance4

Balance5

Balance6

Balance7

Balance8

Balance9

\section{Ant \& Opt}

Pers Flex

Corp Sense

Balance

$.59(.65)$

$.56(.73)$

$.66(.81)$

$.59(.59)$

$.65(.72)$

$.60(.67)$

$.57(.76)$

$.71(.79)$

$.70(.75)$

$.53(.89)$

$.63(.86)$

$.62(.83)$

$.52(.79)$

$.50(.76)$

.67 (.85)

$$
\begin{aligned}
& .65(.68) \\
& .51(.75) \\
& .63(.65) \\
& .74(.86) \\
& .64(.77) \\
& .48(.67) \\
& .52(.59) \\
& .55(.77)
\end{aligned}
$$

$.62(.75)$
$.41(.46)$
$.53(.82)$
$.74(.87)$
$.66(.73)$
$.56(.69)$
$.58(.72)$
$.50(.58)$

$.60(.76)$

$.58(.69)$

$.59(.62)$

$.70(.59)$

$.77(.69)$

$.70(.65)$

$.56(.71)$

$.41(.50)$

$.72(.70)$

$.74(.79)$

$.47(.47)$

$.58(.70)$

$.50(.62)$

$.48(.56)$

$.54(.51)$

$.41(.50)$

Self-ratings: $\chi^{2}(1029)=2004.8, p<0.001, \chi^{2} / d f=1.95, \mathrm{RMSEA}=.051$;

Supervisor ratings: $\chi^{2}(1029)=2821.2, p<0.001, \chi^{2} / d f=2.74, \operatorname{RMSEA}=.069$ )

(All factor loadings are significant at $p<.001$.) 
represent a modern career in which lateral career moves are more frequent (as opposed to the traditional hierarchical career). The results of the analyses can be found in Tables $\mathrm{V}$ and VI. Age, gender, highest educational qualification, years of experience, and managerial activities of the employee were controlled for in the analysis (Step 1). Subsequently, age, gender, and years of supervision (of that particular employee) by the supervisor were controlled for (Step 2). The employability dimensions are imported in Step 3, assessing their predictive value for the career outcome in question. Supervisor ratings are used here to prevent common method bias (Doty \& Glick, 1998). Interestingly enough, each career outcome appeared to be predicted by different employability dimensions, their effects not always being positive. The predictive value of the separate competences for the different career success outcomes is now considered.

Promotion within the organization is not significantly predicted by any of the employability dimensions. Occupational expertise is related positively only to subjective interpersonal success, which is rather remarkable. Occupational expertise is negatively related to the number of promotions in the entire career and, likewise, negatively related to subjective hierarchical success. A negative relationship of the career anchor of technical competence (similar to occupational expertise) with employability was found in earlier studies (Van Dam, 2004). This result could be explained by the fact that experts are very committed to their profession. Following their profession is their primary career goal, which consequently leads to less hierarchical mobility and change.

This result also may be caused by organizations, in the sense that they thrive if people keep on doing what they do best. The fact that we are unable to demonstrate a relationship between occupational expertise and at least the number of periods of unemployment can be explained by the funneling character of expertise. People are overspecialized to the degree that this might have a negative impact on their job acquisition. We strongly assume a positive relationship be- tween occupational expertise and firm outcomes with knowledge intensification.

Anticipation and optimization is a significant predictor for periods of unemployment; the higher the score on this employability dimension, the fewer periods of unemployment employees suffered. Preparing for and adapting to future changes in a personal and creative manner, and striving for the best possible results, indeed seem to protect a person from unemployment. However, anticipation and optimization is negatively related to subjective financial success. A logical explanation would be that employees scoring higher on this dimension are more impatient with regard to increasing their salary.

Personal flexibility is only positively related to periods of unemployment: the higher the score on this employability dimension, the more periods of unemployment employees suffered. Based on our results, a person does not seem to benefit from the capacity to adapt easily to all kinds of changes in the internal and external labor market that do not pertain to one's immediate job domain. We do expect this employability dimension to have a positive relation to firm outcomes though (see, for example, Van Dam, 2004), with negative repercussions on employee outcomes.

Corporate sense appears to be a significant predictor for the number of promotions in the entire career, gross income, and subjective hierarchical success. These results are a strong indicator for the positive impact of the employability dimension on both objective and subjective career success. Participation and performance in different workgroups seem to be very important activities for a person's career success (Seibert et al., 2001).

Finally, balance was positively related to job satisfaction and life satisfaction, both subjective career success outcomes. Compro- 


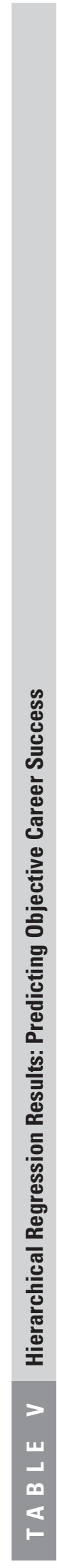

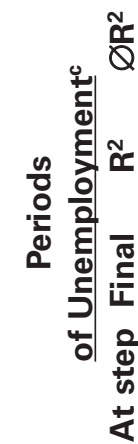

กุ.

ㅊำ ำ

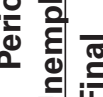

닝ㅇㅇ

荙

ปี่

号

ํํำ

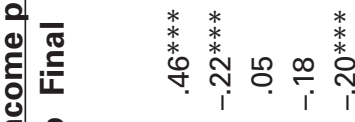

드 웅

$\stackrel{5}{ \pm}$

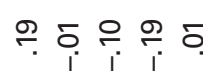

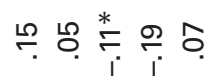

莡

$*$
$*$
$\cdots$
$\cdots$
$*$
$*$
$*$
$*$

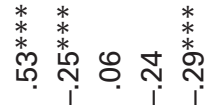

華

ธุ

ฮั ฮ

ํํำ

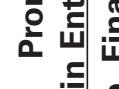

के

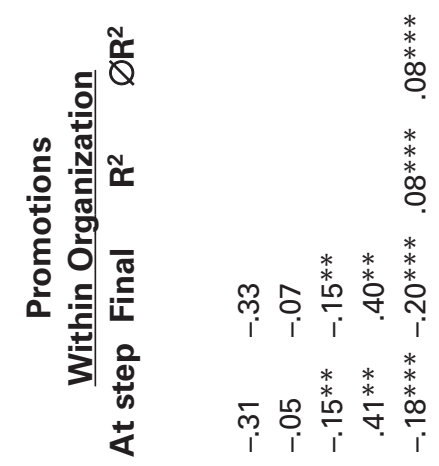

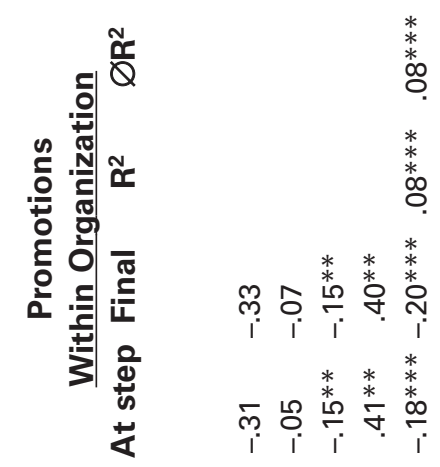

ธ

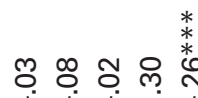

(n)

.

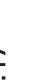

(n)

$\varnothing \overline{0} \stackrel{*}{\stackrel{*}{\leftarrow}}$

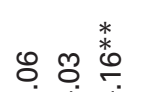

(1)

$\stackrel{*}{*}$

$\stackrel{*}{*}$

ธㅇำ $\stackrel{*}{\stackrel{*}{\leftarrow}}$

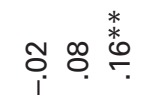

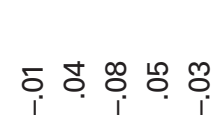

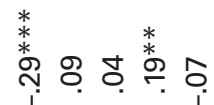

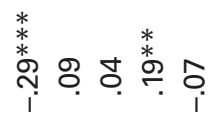

8

$\stackrel{*}{*}$

б

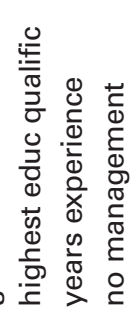

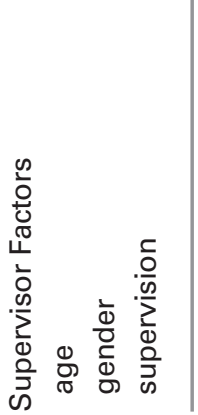

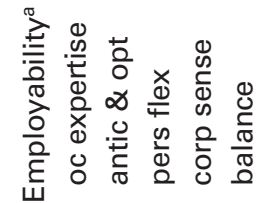

*

$\stackrel{*}{*}$

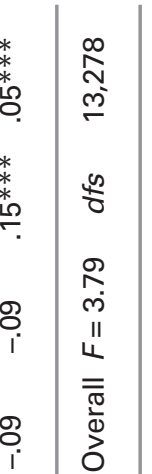

พั่

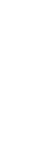

然

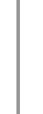

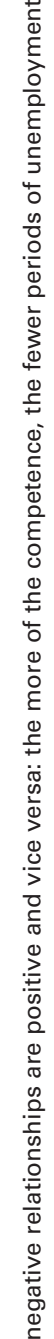

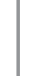




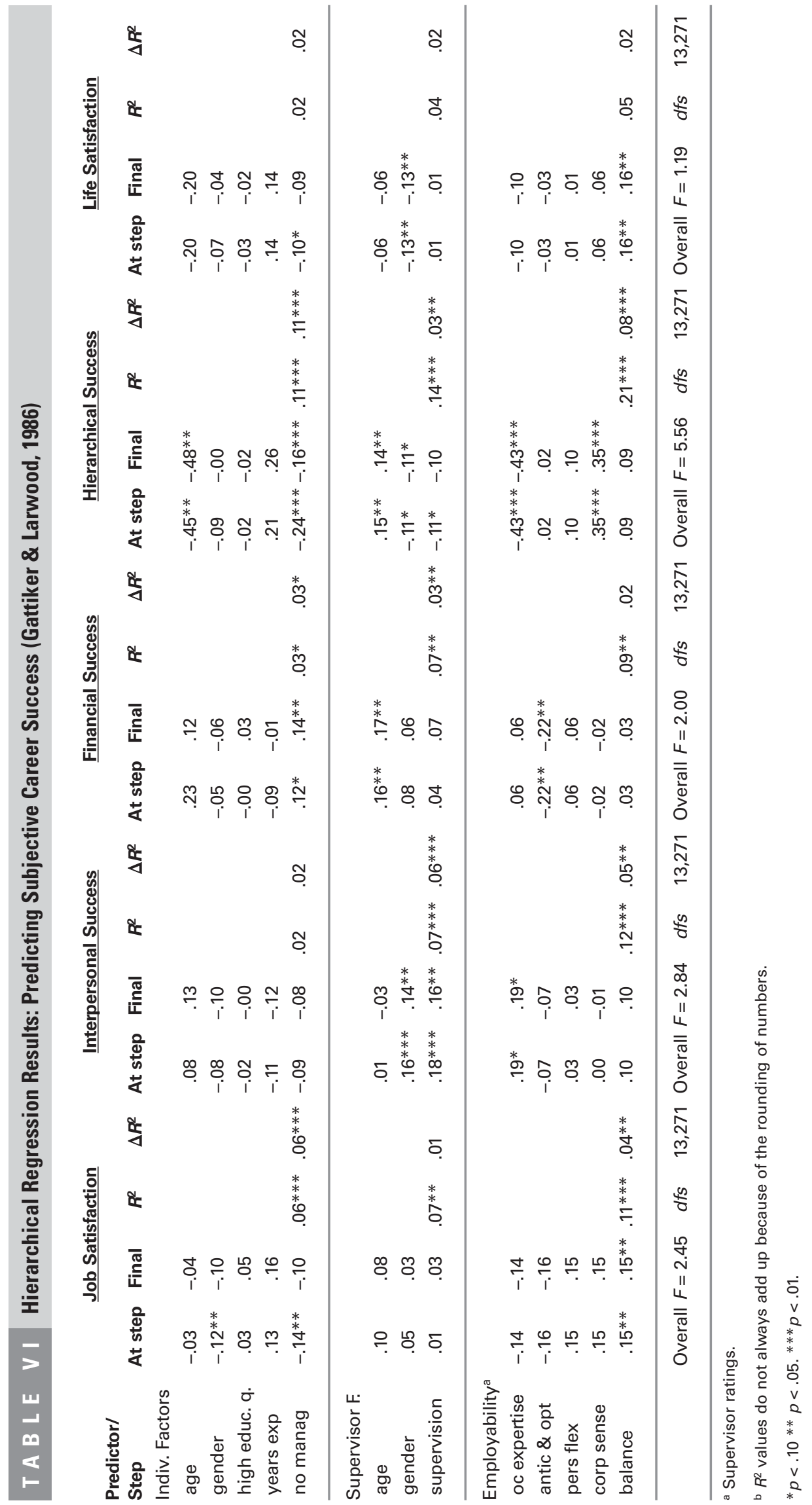


mising between opposing employers' interests as well as one's own opposing interests (employee) and between employers' and employees' interests fulfills an important role. Job satisfaction and life satisfaction are important outcomes for employees in order to maintain their productivity in the long run (Korman, Wittig-Berman, \& Lang, 1981).

measurement

\section{instrument offers a Implications for \\ Practitioners}

user-friendly

opportunity for

practitioners to

monitor

competences of the

organization's

personnel on a

continual basis,

which is helpful to

plan relevant

actions for the

future strategy of

the company and

for other research

objectives.
The validated employability measurement instrument offers a user-friendly opportunity for practitioners to monitor competences of the organization's personnel on a continual basis, which is helpful to plan relevant actions for the future strategy of the company and for other research objectives (such as demonstrating relationships with financial outcomes; see; for example; Cascio, 2005). This will help practitioners in their role as strategic business partners. The instrument is simple to use and can be deployed throughout different sectors and jobs. Practitioners are able to monitor the employability of the employees with this instrument and use it in their annual performance interviews and personal development plans. The instrument presented here has high practical value both for managers, since it is aimed at improving existing evaluation methods used for assessing their subordinates, and for employees, in providing thorough suggestions aimed at improving their career development.

Moreover, the instrument could be deployed with the objective of integrating performance interviews and personal development plans (see also Rodriguez et al., 2002). Differences between supervisor ratings and self-ratings could serve as a fruitful topic of conversation. Our instrument might also be used as a means of comparing competences of employees in different organizational units or departments. The latter might lead to an improvement in recruitment, staffing, and career mobility practices.

\section{Conclusions and Discussion}

In conclusion, in the competence-based approach to employability outlined in this article, employability (1) is advantageous for both career outcomes and firm outcomes, (2) is advantageous for both present performance on the job as well as career outcomes (long-term performance, implying the process of adaptation and learning), (3) in addition to adaptive behavior, may include personal elements such as personality, attitudes, motivation, and ability, and (4) represents the combination of specific and more generic competences.

The measurement of employability presented in this article is based upon the idea that some characteristics of expert performance and of employability are valid regardless of the domain of expertise of a professional. The present study is explorative in the sense that a domain-independent operationalization of employability was nonexistent in the literature. Our study was designed in order to test the psychometric properties of the measures and indicates that the criteria of convergent and discriminant validity have been met to a reasonable extent. A valid and reliable multitrait instrument has been achieved. The five scales appear very homogeneous, for both the self-ratings and for the supervisor ratings. Although employability is thought to be a multidimensional concept, the five dimensions are not fully exclusive and represent correlated aspects of employability. This is why the factor structure is oblique instead of orthogonal.

The distinctive power of the five scales, however, is satisfactory given the higher intrascale correlations, the outcomes of the multitrait-multimethod analysis, and the SEM analyses. These results support our theory, which states that employability involves: (1) occupational expertise, (2) anticipation and optimization, (3) personal 
flexibility, (4) corporate sense, and (5) balance.

One limitation is that the measurement instrument has been tested using only one sample. In the future, we will test the generalizability of our findings by applying the employability theory and measurement instrument in other samples and professional sectors. Another limitation of this study is that only the influence of employability upon employee (career) outcomes has been studied in this contribution. Studying the relationship of employability with firm outcomes is the next important step in this research project. Moreover, the cross-sectional design that we have used for testing the predictive validity of employability for career success should, in future studies, be replaced with longitudinal studies to prevent reverse causation (Wright, Gardner, Moynihan, \& Allen, 2005).

The predictive validity of the employability measurement instrument upon objective and subjective career success measures has been demonstrated. For most career success measures, the predictive role of employability is significant. All five employability dimensions appear to be significantly related to one or more of the career success measures. The pattern varies for the different career success measures. In some cases, there is a negative or null relationship between the employability dimension and the career success measure (especially in the case of occupational expertise and personal flexibility). Nonetheless, overall we expect that certain employability competences indeed stimulate particular career outcomes and consequently positively influence organizational outcomes. This assumption needs to be further explored and tested in new studies.

Using both self-ratings and supervisor ratings is of great importance. The disagreement between supervisors and employees on the employability dimensions is indicative of the difficulty of evaluating employability. The suggestion made by Van der Heijden (2000) to use think-aloud protocols aimed at explaining why a rater gives a particular rating to a particular item might also be used in the near future. It is possible that this technique will improve the validity of the instru- ment, albeit at the expense of the homogeneity of the scales. If raters are asked to provide concrete examples of performances or behaviors of the ratees, response sets such as the halo effect will probably be sifted out, at least to a certain extent. If raters have to justify their choices and are encouraged to think more carefully about their answers, the differentiation between item meanings will probably increase, leading to a further increase in valid outcomes.

Only if ratings are explicitly based on empirical, verifiable observations of behavior and performance can we use them confidently in annual job and career assessments. The instrument presented here has high practical value both for managers (aimed at improving existing evaluation methods used for assessing their subordinates) and for employees (in providing thorough suggestions aimed at improving their career development). The proposed measurement instrument enables us to further investigate the relationship between individual, jobrelated, and organizational career activities and characteristics on the one hand and employability on the other hand. This might eventually produce useful recommendations for enhancing lifelong career success. Knowledge concerning these relationships is desirable from both an organizational and an individual perspective.

...overall we expect
that certain
employability
competences
indeed stimulate
particular career
outcomes and
consequently
positively influence
organizational
outcomes.

\section{Acknowledgments}

This study has been financed by NWO, Netherlands Organization for Scientific Research, as an ASPASIA-Program. This study also forms part of a cross-cultural project, entitled Indic@tor, that has been partly financed by the European Commission, IST program (project ID: IST-200031070). We wish to thank H. C. M. Vorst of the University of Amsterdam in the Netherlands for his elaborate contributions to the data analysis. We also thank the editor and anonymous reviewers for helpful comments on the manuscript. 
CLAUDIA M. VAN DER HEIJDE is an assistant professor in the Department of Management and Organization of the Faculty of Economics and Business Administration at the Vrije Universiteit Amsterdam, the Netherlands. She holds an M. A. in psychology from the University of Amsterdam. After her studies, she worked as a researcher and consultant for profit and nonprofit organizations on HRM and diversity issues. Her area of expertise is quantitative research, particularly the development of questionnaires and measurement instruments. She also built a substantial amount of expertise working for large research projects funded by the European Social Fund (ESF), such as IST and Equal. She is also affiliated with the University of Twente, the Netherlands, in the HRM department of the School of Business, Public Administration, and Technology, where she started her $\mathrm{PhD}$ research on employability and age management.

BEATRICE I. J. M. VAN DER HEIJDEN is working as the director of research and doctoral programs at the Maastricht School of Management in the Netherlands. She is also head of the Department of Organizational Behavior. She holds a chair in strategic HRM at the Open University of the Netherlands and is also affiliated with the University of Twente, the Netherlands, in the HRM department of the School of Business, Public Administration, and Technology. Her main research areas are career development, employability, and aging at work. Currently, she is coordinating two European cross-cultural research projects on career outcomes and their individual, job-related and organizational predictor variables. She serves as a member of the editorial boards of Ergonomia, Gedrag en Organisatie, Personeelbeleid, SAM, Advanced Management Journal, and Systems Practice and Action, and is a guest editor for several journals in the field of HRM and work and organizational psychology.

\section{REFERENCES}

Arbuckle, J. L., \& Wothke, W. (1999). AMOS software and 4.0 user's guide. Chicago, IL: SmallWaters Corporation.

Arnold, J., \& MacKenzie Daveys, K. (1992). Self-ratings and supervisor ratings of graduate employees' competences during early career. Journal of Occupational and Organizational Psychology, 65, 235-250.

Athey, T. R., \& Orth, M. S. (1999). Emerging competency methods for the future. Human Resource Management, 38, 215-226.

Baerveldt, M., \& Hobbs, G. (1988). Forces reshaping the future organization and management of work: A perspective from a Canadian oil company. In $\mathrm{R}$. J. Neihaus \& K. F. Price (Eds.), Creating the competitive edge through human resource applications (pp. 47-62). New York: Plenum.

Ball, B. (1997). Career management competencesThe individual perspective. Career Development International, 2, 74-79.

Barnett, W. P., \& Miner, A. S. (1992). Standing on the shoulders of others: Career interdependence in job mobility. Administrative Science Quarterly, 37, 262-281.
Barney, J. B. (1991). Firm resources and sustained competitive advantage. Journal of Management, $17,99-120$.

Baruch, Y. (2001). Employability: A substitute for loyalty? Human Resource Development International, 4, 543-566.

Bhaerman, R., \& Spill, R. (1988). A dialogue on employability skills: How can they be taught? Journal of Career Development, 15, 41-52.

Boerlijst, J. G. (1994). The neglect of growth and development of employees over 40 in organizations: A managerial and training problem. In J. Snel \& R. Cremer (Eds.), Work and aging (pp. 251-271). London:Taylor \& Francis Ltd.

Bolweg, J. F. (1997). De onmogelijkheid van consistent sociaal beleid [The impossibility of a consistent social policy]. Deventer: Kluwer.

Bolweg, J. F., \& Maenhout, J. M. M. (1995). Full employability: Economisch noodzakelijk, sociologisch naïef? [Full employability: Economic necessity, sociologic naïveté?]. In L. Faase, M. Ott, \& C. J. Vos (Eds.), Nieuwe breukvlakken in het arbeidsbestel? (pp. 92-99). Utrecht: DeTijdstroom.

Borman, W. C. (1974). The rating of individuals in organizations: An alternative approach. Organiza- 
tional Behavior and Human Performance, 12, 105-124.

Boselie, P., \& Pauwe, J. (2004). Human resource management en prestatieverbetering: Een overzicht van 10 jaar onderzoek [Human resource management and performance improvement: A review of 10 years' research]. Unpublished paper.

Boudreau, J. W., Boswell, W. R., \& Judge, T. A. (2001). Effects of personality on executive career success in the United States and Europe. Journal of Vocational Behavior, 58, 53-81.

Boxall, P. (1999). The strategic HRM debate and the resource-based view of the firm. In R. S. Schuler \& S. E. Jackson (Eds.), Strategic human resource management (pp. 73-89). Oxford, UK: Blackwell Business.

Campbell, D. J., \& Lee, C. (1988). Self-appraisal in performance evaluation: Development versus evaluation. Academy of Management Review, 13, 302-314.

Campbell, D. T., \& Fiske, D. W. (1959). Convergent and discriminant validation by the multitrait-multimethod matrix. Psychological Bulletin, 56(2), 81-105.

Capelli, P., \& Crocker-Hefter, A. (1996). Distinctive human resources are firms' core competencies. Organizational Dynamics, 24(3), 7-22.

Cascio, W. F. (2005). From business partner to driving business success: The next step in the evolution of HR management. Human Resource Management, 44, 159-163.

Chapman, G. M., \& Martin, J. F. (1995). Computerized business games in engineering education. Computers \& Education, 25(1/2), 67-73.

Cheng, E. W. L., \& Ho, D. C. K. (2001). The influence of job and career attitudes on learning motivation and transfer. Career Development International, 6, 20-27.

Crant, J. M. (2000). Proactive behavior in organizations. Journal of Management, 26, 435-462.

Cronbach, L. J. (1990). Essentials of psychological testing. New York: HarperCollins.

Cudeck, R., \& Browne, M. W. (1993). Alternative ways of assessing model fit. In K. A. Bollen \& J. Scott Long (Eds.), Testing structural equation models (pp. 1-9). Newbury Park, CA: Sage.

DeFillippi, R. J., \& Arthur, M. B. (1996). Boundaryless contexts and careers: A competency-based perspective. In M. B. Arthur \& D. M. Rousseau (Eds.), The boundaryless career: A new employment principle for a new organizational era (pp. 116-131). New York: Oxford University Press.
De Grip, A., Van Loo, J., \& Sanders, J. (2004). The industry employability index: Taking account of supply and demand characteristics. International Labour Review, 143, 211-233.

De Groot, A. D. (1961). Methodologie. Grondslagen van onderzoek en denken in de gedragswetenschappen [Methodology. Foundations of research and thinking in the behavioral sciences]. Den Haag: Uitgeverij Mouton.

De Haan, E. G., Vos, P. J., \& De Jong, Ph. R. (1994). Flexibiliteit van de arbeid [Labor flexibility]. Den Haag: Welboom.

De Lange, W. A. M. (2001). Flexibilisering van de arbeid en flexibilisering van de organisatie-Incompatibilité des humeurs? [Labor flexibility and organizational flexibility-Incompatible?]. In P. Ester, R. Muffels, \& J. Schippers (Eds.), Flexibilisering, organisatie en employability (pp. 40-56). Bussum: Coutinho.

Doty, D. H., \& Glick, W. H. (1998). Common methods bias: Does common methods variance really bias results? Organizational Research Methods, 1, 374-406.

Dweck, C. S., \& Leggett, E. L. (1988). A social-cognitive approach to motivation and personality. Psychological Review, 95, 256-273.

Enders, J. (2002). Governing the academic commons: About blurring boundaries, blistering organisations, and growing demands. Inaugural lecture. In The CHEPS Inaugurals 2002, (pp. 69-105). Enschede: University of Twente.

Facteau, J. D., \& Craig, S. B. (2001). Are performance appraisal ratings obtained from different rating sources comparable? Journal of Applied Psychology, 86, 215-227.

Felstead, A., \& Ashton, D. N. (2000). Tracing the link: Organizational structures and skill formation. Human Resource Management Journal, 10(3), 5-21.

Forrier, A., \& Sels, L. (2003). The concept employability: A complex mosaic. International Journal of Human Resources Development and Management, 3, 102-124.

Frese, M. (2000). The changing nature of work. In N. Chmiel (Ed.), Introduction to work and organizational psychology (pp. 424-439). Oxford, UK: Blackwell.

Friedrichs, J. H. (2000). Personeel steeds meer rots in de branding: Employability als drijvende kracht achter veranderingen [Personnel, relying on them more and more: Employability as driving force behind changes]. Gids voor Personeelsmanagement, 79, 36-38. 
Fugate, M., Kinicki, A. J., \& Ashforth, B. E. (2004). Employability: A psycho-social construct, its dimensions, and applications. Journal of Vocational Behavior, 65, 14-38.

Gaspersz, J., \& Ott, M. (1996). Management van employability. Nieuwe kansen in arbeidsrelaties [Management of employability. New opportunities in labor relations]. Assen: Van Gorcum/Stichting Management Studies.

Gattiker, U. E., \& Larwood, L. (1986). Subjective career success: A study of managers and support personnel. Journal of Business and Psychology, 1, 78-94.

Gazier, B. (1990). L’Employabilité: Brève radiographie d'un concept en mutation. [Employability: Short registration of a changing concept]. Sociologie du Travail, 32, 575-584.

Geelhoed, L. A. (1997). Flexibilisering van de arbeid, deregulering en marktwerking. [Labor flexibility, deregulation and free market mechanism]. In G. Faber \& J. Schippers (Eds.), Flexibilisering van arbeid (pp. 29-40). Bussum: Coutinho.

Guest, D. (1987). Human resource management and industrial relations. Journal of Management Studies, 24, 503-521.

Gunz, H., Evans, M., \& Jalland, M. (2000). Career boundaries in a "boundaryless world." In M. A. Peiperl, M. B. Arthur, R. Goffee, \& T. Morris (Eds.), Career frontiers: New conceptions of working lives (pp. 24-53). Oxford, UK: University Press.

Hall, D. T. (1976). Careers in organizations. Pacific Palisades, CA: Goodyear.

Handy, C. (1994). The age of paradox. Cambridge, MA: Harvard Business School Press.

Harris, M. M., \& Schaubroeck, J. (1988). A meta-analysis of self-supervisor, self-peer, and peer-supervisor ratings. Personnel Psychology, 41, 43-62.

Harvey, L. (2001). Defining and measuring employability. Quality in Higher Education, 7, 97-109.

Hennessey, H. W., Jr., \& Bernardin, H. J. (2003). The relationship between performance appraisal criterion, specificity, and statistical evidence of discrimination. Human Resource Management, 42, 143-158.

Hoeksema, L., \& Paauwe, J. (1996). Employability: De inzetbaarheid van personeel binnen en buiten de organisatie. [Employability: The deployment of personnel within and outside the organization] In A. Stads \& N. Verbeek (Eds.), Human resource management, een praktisch handboek voor operationeel leidinggeven, 3 (pp. 102-132). Utrecht:Teleac.

Hoffman, C. C., Nathan, B. R., \& Holden, L. M. (1991). A comparison of validation criteria: Objective versus subjective performance measures and self- versus supervisor ratings. Personnel Psychology, 44, 601-619.

Holzbach, R. L. (1978). Rater bias in performance ratings: Superior, self-, and peer ratings. Journal of Applied Psychology, 63, 579-588.

Jöreskog, K. G. (1969). A general approach to confirmatory maximum likelihood factor analysis. Psychometrika, 34, 183-202.

Kidder, L. H., \& Judd, C. M. (1986). Research methods in social relations. New York: CBS College Publishing.

Klimoski, R. J., \& London, M. (1974). Role of the rater in performance appraisal. Journal of Applied Psychology, 59, 445-45I.

Kluytmans, F., \& Ott, M. (1999). Management of employability in The Netherlands. European Journal of Work and Organizational Psychology, 8, 261-272.

Korman, A., Wittig-Berman, U., \& Lang, D. (1981). Career success and personal failure: Alienation in professionals and managers. Academy of Management Journal, 24, 342-360.

Lawler, E. E., III. (1994). From job-based to competency-based organizations. Journal of Organizational Behavior, 15, 3-15.

Legge, K. (1995). Human resource management: Rhetorics and realities. Basingstoke, UK: MacMillan.

London, M., \& Greller, M. M. (1991). Demographic trends and vocational behavior: A twenty year retrospective and agenda for the 1990s. Journal of Vocational Behavior, 38, 125-164.

Looise, J. C. (1998). Competentiemanagement en personeelsmanagement. Het gevaar van oude valkuilen en eenzijdige visies [The management of competences and the management of personnel]. Opleiding en Ontwikkeling, 10, 24-28.

Mabe, P., \& West, S. (1982). Validity of self-evaluation of ability: A review and meta-analysis. Journal of Applied Psychology, 67, 280-296.

Marginson, P. (1989). Employment flexibility in large companies: Change and continuity. Industrial Relations Journal, 20, 101-109.

Marsh, H. W. (1987). The hierarchical structure of selfconcept and the application of hierarchical confirmatory factor analysis. Journal of Educational Measurement, 24, 17-39.

Mayer, J. D., \& Salovey, P. (1997). What is emotional intelligence? In P. Salovey \& D. Sluyter (Eds.), Emotional development and emotional intelligence: Implications for educators (pp. 3-31). New York: Basic Books.

McClelland, D. C. (1973). Testing for competence 
rather than for intelligence. American Psychologist, $28,1-14$.

Mikkelsen, A., Nybø, G., \& Grønhaug, K. (2002). Exploring the impact of deregulation on HRM: The case of the Norwegian energy sector. International Journal of Human Resource Management, 13, 1-16.

Miles, R. E., \& Snow, C. C. (1996). Twenty-first-century careers. In M. B. Arthur \& D. M. Rousseau (Eds.), The boundaryless career: A new employment principle for a new organizational era (pp. 116-131). New York: Oxford University Press.

Mulder, M. (2001). Competence development-Some background thoughts. Journal of Agricultural Education and Extension, 7, 147-159.

Nahapiet, J., \& Ghoshal, S. (1998). Social capital, intellectual capital, and the organizational advantage. Academy of Management Review, 23, 242-266.

Nordhaug, O., \& Grønhaug, K. (1994). Competences as resources in firms. International Journal of Human Resource Management, 5, 89-106.

North, J., Mallabar, M., \& Desrochers, R. (1988). Vocational preparation and employability development. Child Welfare, 67, 573-585.

Onstenk, J. H. A. M. (1997). Lerend leren werken. Brede vakbekwaamheid en de integratie tussen werken, leren en innoveren. [Learning to learn at work. Broad occupational competence and the integration between working, learning, and innovating]. Delft: Eburon.

Onstenk, J. H. A. M., \& Kessels, J. (1999). Employability: Arbeidsmarkt, brede vakbekwaamheid en burgerschap. [Employability: Labor market, broad occupational competence, and citizenship]. Comenius, $19,113-132$.

Oosterveld, P., \& Vorst, H. C. M. (1996). Testconstructie en testonderzoek. Methoden van vragenlijstconstructie. [Test construction and test research. Methods of questionnaire construction]. Amsterdam: UVA.

Orlikowski, W. J. (2002). Knowing in practice: Enacting a collective capability in distributed organizing. Organization Science, 13, 249-273.

Paauwe, J. (1997, October 14). Zonder eerlijke ruilrelatie geen employability. [No employability without an honest exchange relationship].Trouw, p. 11.

Pearson, R. W. (1988). Creating flexible careers: Some observations on a "bridge" programme for unemployed professionals. British Journal of Guidance and Counselling, 16, 250-267.

Perkins, D., \& Salomon, G. (1992). Transfer of learning.
International encyclopedia of education (2nd ed.). Oxford, UK: Pergamon Press.

Podsakoff, P. M., MacKenzie, S. B., Paine, J. B., \& Bachrach, D. G. (2000). Organizational citizenship behaviors: A critical review of the theoretical and empirical literature and suggestions for future research. Journal of Management, 26, 513-563.

Prahalad, C. K., \& Hamel, G. (1990). The core competence of the corporation. Harvard Business Review, 68(3), 79-91.

Rodriguez, D. A., Patel, R., Bright, A., Gregory, D., \& Gowing, M. K. (2002). Developing competency models to promote integrated human resource practices. Human Resource Management, 41, 309-324.

Rothwell, W. J., \& Lindholm, J. E. (1999). Competency identification, modelling and assessment in the USA. International Journal of Training and Development, 3, 90-105.

Sandberg, J. (2000). Understanding human competence at work: An interpretative approach. Academy of Management Journal, 43, 9-25.

Scarbrough, H. (1998). Path(ological) dependency? Core competencies from an organizational perspective. British Journal of Management, 9, 219-232.

Schein, E. H. (1996). Career anchors revisited: Implications for career development in the 21st century. Academy of Management Executive, 10(4), 80-88.

Schumacker, R. E., \& Lomax, R. G. (1996). A beginner's guide to structural equation modeling. New York: Lawrence Erlbaum Associates.

Seibert, S. E., Kraimer, M. L., \& Liden, R. C. (2001). A social capital theory of career success. Academy of Management Journal, 44, 219-237.

Steijn, B. (2002). De komst van nieuwe productie-concepten en andere arbeidsrelaties: Sneltrein of boemel? [The arrival of new production concepts and other labor relations: Fast or slow train?]. Tijdschrift voor HRM, 2, 7-24.

Sternberg, R. J. (1996). Successful intelligence. New York: Simon \& Schuster.

Sternberg, R. J. (1999). Successful intelligence: Finding a balance. Trends in Cognitive Sciences, 3, 436-442.

Sterns, H. L., \& Dorsett, J. G. (1994). Career development: A life span issue. Experimental Aging Research, Special Issue on Cognition, Work, Technology and Environmental Design for the Elderly, 20, 257-264.

Thijssen, J. G. L. (1996). Leren, leeftijd en loopbaanperspectief. Opleidingsdeelname door oudere per- 
soneelsleden als component van human resource development [Learning, aging and career prospect]. Unpublished doctoral thesis, Catholic University Brabant.

Thijssen, J. G. L., \& Van der Heijden, B. I. J. M. (2003). Employability in the focus of attention. In M. J. Morley, P. Gunnigle, N. Heraty, J. Pearson, H. Shiekh, \& S. Tiernan (Eds.), Exploring the mosaic: Developing the discipline (pp. 229-239). Dublin: Interesource Group Limited.

Thornton, G. C., III. (1980). Psychometric properties of self-appraisals of job performance. Personnel Psychology, 33, 263-271.

Thornton, G. C., III, \& Byham, W. C. (1982). Assessment centers and managerial performance. New York: Academic Press.

Valverde, M., Tregaskis, O., \& Brewster, C. (2000). Labor flexibility and firm performance. International Advances in Economic Research, 6, 649-661.

Van Beckhoven, G.M. (1997, June). Employability en loopbaan. [Employability and career]. NIVE Management Magazine, pp. 15-19.

Van Dam, K. (2004). Antecedents and consequences of employability orientation. European Journal of Work and Organizational Psychology, 13, 29-51.

Van Dam, K., \& Thierry, H. (2000). Mobiliteit in perspectief: Een overzicht van onderzoek rond de mobiliteit van personeel. [Mobility in perspective: $\mathrm{A}$ review of studies on the mobility of personnel]. Gedrag \& Organisatie, 13, 29-50.

Van der Heijde, C. M., \& Van der Heijden, B. I. J. M. (2005). The development and psychometric evaluation of a multi-dimensional measurement instrument of employability-and the impact of ageing. In G. Costa, W. J. A. Goedhard, \& J. Ilmarinen (Eds.), Assessment and promotion of work ability, health and well-being of ageing workers. Proceedings of the 2nd International Symposium on Work Ability, Verona, Italy, October 18-20, 2004. International Congress Series (ICS) 1280. San Diego, CA: Elsevier.

Van der Heijden, B. I. J. M. (2000). The development and psychometric evaluation of a multidimensional measurement instrument of professional expertise. High Ability Studies, 11, 9-39.

Van der Heijden, B. I. J. M. (2005, September 30). No one has ever promised you a rose garden. On shared responsibility and employability enhancing practices throughout careers. Inaugural lecture, MSM/OU. Assen: Van Gorcum.
Van der Heijden, B. I. J. M., \& Thijssen, J. G. L. (2003). Editorial: HRD and employability. International Journal of Human Resources Development and Management, 3, 99-101.

Van der Heijden, B. I. J. M., \& Verhelst, N. D. (2002). The psychometric evaluation of a multi-dimensional measurement instrument of professional expertise. Results from a study in small and mediumsized enterprises in the Netherlands. European Journal of Psychological Assessment, 18, 165-178.

Van der Heijden, Th. J., Volz, A. B., Reidinga, H. F., \& Schutte, R. J. (2001). Competentiemanagement. Van belofte naar verzilvering [Management of competences]. Alphen aan den Rijn: Samsom/NVP.

Van der Krogt, F. J. (1998). Learning network theory: The tension between learning systems and work systems in organizations. Human Resource Development Quarterly, 9, 157-177.

Van Lammeren, C. (1999). De veranderende betekenis van employability [The changing meaning of employability]. Gids voor de Opleidingspraktijk, 28, 1-23.

Versloot, A. M., Glaudé, M.Th., \&Thijssen, J. G. L. (1998). Employability: Een pluriform arbeidsmarktfenomeen [Employability: A multiform job market phenomenon]. Amsterdam: Max Goote/ Synopsis.

Weick, K. E. (1996). Enactment and the boundaryless career: Organizing as we work. In M. B. Arthur \& D. M. Rousseau (Eds.), The boundaryless career: A new employment principle for a new organizational era (pp. 40-57). Oxford, UK: Oxford University Press.

Wood, R. E., \& Bandura, A. (1989). Impact of conceptions of ability on self-regulatory mechanisms and complex decision making. Journal of Personality and Social Psychology, 56, 407-415.

Wright, P. M., Gardner, T. M., Moynihan, L. M., \& Allen, M. R. (2005). The relationship between HR practices and firm performance: Examining causal order. Personnel Psychology, 58, 409-446.

Wright, P. M., McMahan, G. C., \& McWilliams, A. (1994). Human resources and sustained competitive advantage: A resource-based perspective. International Journal of Human Resource Management, 5, 301-326.

Wright, P. M., \& Snell, S. A. (1998). Toward a unifying framework for exploring fit and flexibility in strategic human resource management. Academy of Management Review, 23, 756-772. 


\section{A P P E N DIX A}

\section{Occupational Expertise}

1. I consider myself competent to engage in in-depth, specialist discussions in my job domain.

2. During the past year, I was, in general, competent to perform my work accurately and with few mistakes.

3. During the past year, I was, in general, competent to take prompt decisions with respect to my approach to work.

4. I consider myself competent to indicate when my knowledge is insufficient to perform a task or solve a problem.

5. I consider myself competent to provide information on my work in a way that is comprehensible.

6. In general, I am competent to distinguish main issues from side issues and to set priorities.

7. During the past year, I was, in general, competent to carry out my work independently.

8. I consider myself competent to be of practical assistance to colleagues with questions about the approach to work.

9. I consider myself competent to weigh up and reason out the "pros" and "cons" of particular decisions on working methods, materials, and techniques in my job domain.

10. Overall, how do you see yourself in terms of your work performance?

11. How much confidence do you have in your capacities within your area of expertise?

12. How would you rate the quality of your skills overall?

13. What proportion of your work would you say you brought to a successful conclusion in the past year?

14. I have a _ opinion of how well I performed in the past year.

15. During the past year, how sure of yourself have you felt at work?

\section{Anticipation and Optimization}

1. How much time do you spend improving the knowledge and skills that will be of benefit to your work?

2. I take responsibility for maintaining my labor market value.

3. I approach the development of correcting my weaknesses in a systematic manner.

4. I am focused on continuously developing myself.

5. I consciously devote attention to applying my newly acquired knowledge and skills.

6. In formulating my career goals, I take account of external market demand.

7. During the past year, I was actively engaged in investigating adjacent job areas to see where success could be achieved.

8. During the past year, I associated myself with the latest developments in my job domain.

\section{Personal Flexibility}

1. How easily would you say you can adapt to changes in your workplace?

2. How easily would you say you are able to change organizations, if necessary?

3. I adapt to developments within my organization.

4. How quickly do you generally anticipate and take advantage of changes in your working environment?

5. How quickly do you generally anticipate and take advantage of changes in your sector?

6. How much variation is there in the range of duties you aim to achieve in your work?

7. I have a ___ (very negative-very positive) attitude to changes in my function.

8. I find working with new people (very unpleasant-very pleasant). 


\section{A P P E N D I X A (continued)}

\section{Corporate Sense}

1. I am involved in achieving my organization's/department's mission.

2. I do that extra bit for my organization/department over and above my direct responsibilities.

3. I support the operational processes within my organization.

4. In my work, I take the initiative in sharing responsibilities with colleagues.

5. In my organization, I take part in forming a common vision of values and goals.

6. I share my experience and knowledge with others.

7. How much influence do you exercise within your organization?

\section{Balance}

1. I suffer from work-related stress.

2. My work and private life are evenly balanced.

3. My working, learning, and living are in harmony.

4. My work efforts are in proportion to what I get back in return (e.g., through primary and secondary conditions of employment, pleasure in work).

5. The time I spend on my work and career development on the one hand and my personal development and relaxation on the other are evenly balanced.

6. I achieve a balance in alternating between a high degree of involvement in my work and a more moderate one at the appropriate moment.

7. After working, I am generally able to relax.

8. I achieve a balance in alternating between reaching my own work goals and supporting my colleagues.

9. I achieve a balance in alternating between reaching my own career goals and supporting my colleagues. 